\title{
Exploitation of Simultaneous Alcoholic and Malolactic Fermenta- tion of Incrocio Manzoni, a Traditional Italian White Wine
}

\author{
R. Guzzon ${ }^{1 *}$, S. Moser ${ }^{1}$, S. Davide ${ }^{1}$, T.R. Villegas ${ }^{1}$, M. Malacarne ${ }^{1}$, R. Larcher ${ }^{1}$, T. Nardi ${ }^{2}$, P. Vagnoli ${ }^{3}$, S. Krieger-Weber $^{4}$ \\ (1) Edmund Mach Foundation, Via Edmund Mach 1, 38010 San Michele all'Adige (Trento), Italy \\ (2) CREA Consiglio per la ricerca in agricoltura e l'analisi dell'economia agrarian, Via di Corticella 133, 40128 Bologna (BO), \\ Italy \\ (3) Lallemand Italia, Via Rossini 14/B, 37060 Castel D’Azzano (VR), Italy \\ (4) Lallemand, In den Seiten, 53D-70825 Korntal-Münchingen, Germany
}

Submitted for publication: February 2016

Accepted for publication: April 2016

Key words: Wine, lactic bacteria, malolactic fermentation, Incrocio Manzoni, volatile compounds

\begin{abstract}
Malolactic fermentation (MLF) is a key feature in the production of high-quality wines. Its evolution is not always guaranteed, especially in white wine, due to certain limiting factors (low pH, sulphur dioxide, low temperature) acting against malolactic bacteria. The inoculation of grape must with bacteria is an alternative approach to the management of oenological fermentation, favouring the survival of bacteria due to the absence of ethanol or sulphur dioxide - toxic compounds made by yeasts in the first stages of winemaking. We compared the activity of two strains of Oenococcus oeni during MLF in wines made from an emerging white grape variety, native to north-eastern Italy, namely Incrocio Manzoni. Different winemaking protocols were assayed, comparing sequential or simultaneous inoculation of microbial starters. The monitoring of bacterial viability through fermentations and a comprehensive characterisation of the volatile profile of the wines were achieved by advanced analytical approaches, flow cytometry and GC-MS respectively. According to the preliminary hypothesis, the chemical composition of the grape must was characterised by high acidity, which represented a serious barrier to bacterial development. Simultaneous inoculation of the two $O$. oen $i$ strains ensured a regular evolution of MLF. Some differences were highlighted, both in terms of fermentation kinetics and the aromatic profile of the wines obtained, in relation to the strain of lactic bacteria. The work provides an exhaustive overview of the opportunities and risks related to different wine fermentation approaches in order to enhance the quality of white wines made from "new" or "local" wine grapes.
\end{abstract}

\section{INTRODUCTION}

Malolactic fermentation (MLF), the biological conversion of the malic acid of wine into lactic acid, is one of the fundamental bio-transformations occurring during winemaking (Renouf, 2013). This process takes place in almost all red wines and in an increasing proportion of white and sparkling wines, due to the noticeable improvement in their microbiological stability and organoleptic characteristics (Bartowsky et al., 2015). Despite this, malolactic fermentation causes several concerns among winemakers because its evolution cannot be guaranteed (Henick-Kling, 1993; Liu, 2002; Bauer \& Dicks, 2004). Wine is not a suitable environment for microbial growth because of the simultaneous presence of certain chemical factors that are able to limit bacterial activity, including ethanol, sulphur dioxide, low $\mathrm{pH}$ and the absence of fermentable sugars (Liu \& Gallander, 1983; Wibowo et al., 1985; Guzzo et al., 2002; Rosi et al., 2003; Zapparoli et al., 2009). Some authors have highlighted other causes of problems during MLF, including nutritional imbalance and/or toxic compounds made by the yeast responsible for alcoholic fermentation (Comitini \& Ciani, 2007). The sum of these factors can cause delays or stuck MLF, with the risk of wine depreciation associated with the occurrence of spoilage phenomena and/or the production of toxic compounds due to indigenous microflora (Lonvaud-Funel, 1999; Spano et al., 2010). The main difficulties in achieving MLF have been observed in the northernmost wine regions due to the pronounced acidity. Wines with a $\mathrm{pH}$ of below 3.3 can lead to bacterial stress, making even selected bacterial cultures ineffective if they are not specifically adapted to extremely acidic conditions (Drici Cachon et al., 1996). These experiences suggest that alternative approaches are needed to the management of MLF, including the simultaneous fermentation of yeast and bacteria.

*Corresponding author: E-mail address: raffaele.guzzon@fmach.it [Tel. +39 0461 615319; Fax +39 0461615288$]$

Acknowledgements: We would like to thank the colleagues at the Chimica Vitienologica e Agroalimentare operational units of the Edmund Mach Foundation, for their support in relation to this work, and the staff of the Experimental Winery of the Edmund Mach Foundation, for their effective contribution to the results of this research 
The lactic acid bacteria responsible for MLF belong to the Lactobacillus, Pediococcus and Oenococcus genera. Before the advent of starter cultures of selected malolactic bacteria, MLF could take place thanks to the indigenous microflora belonging to these genera that can develop in wine following alcoholic fermentation (Wibowo et al., 1985; Francesca et al., 2011). Today the most common approach to MLF is the inoculation of selected malolactic bacteria of which the characteristics, in terms of resistance to wine limiting factors, have already been verified and proven in wine (Costello et al., 2003; Coucheney et al., 2005; Lasik, 2013). However, this is not always enough to ensure the evolution of MLF, especially in white wines, in which acidity and sulphur dioxide are frequently out of the range suitable for optimal bacterial activity (Henick-Kling, 1993; Liu, 2002). Simultaneous fermentation (also known as yeast-bacteria co-inoculation) means the inoculation of selected cultures of bacteria in the grape must, approximately 24 to 48 hours after the active dry yeast, once the yeast culture has begun alcoholic fermentation (Knoll et al., 2012; Guzzon et al., 2013; Munoz et al., 2014). Grape must is an environment more suitable than wine for microbial growth because it does not contain some of the limiting factors mentioned above; in these conditions, better adaptation and activity of malolactic bacteria are expected. The obstacles to microbial activity, in particular ethanol, accumulate gradually during alcoholic fermentation, allowing time for bacterial biomass adaptation and ensuring a greater chance of survival for lactic acid bacteria. Considering that the consumption of sugar and malic acid can occur simultaneously, the bacteria utilised in this kind of fermentation must be tailored specifically to avoid spoilage phenomena associated with the consumption of sugar by lactic acid bacteria via heterolactic fermentation (Jussier et al., 2006; Pan \& De Orduna, 2006; Zapparoli et al., 2009).

In this work we describe the trials conducted at the experimental winery of the Edmund Mach Foundation (Italy) devoted to evaluate the result of simultaneous fermentations applied in the winemaking of an emerging Italian grape variety, Incrocio Manzoni. This white grape variety results from studies conducted by the Italian agronomist and scientist, Luigi Manzoni (1888 to 1968) in the 1920s, aimed at obtaining new vine cultivars resistant to the main diseases that affect viticulture. Specifically, the vine variety known as Incrocio Manzoni 6.0.13 is made of a cross between Riesling and Pinot Blanc. Today, Incrocio Manzoni is exciting growing interest in northern Italy, and a study of the most appropriate protocol for the management of wine fermentations is a decisive step in incentivising its production. The present study monitored the evolution of the oenological fermentation and chemical profile of wines made by different styles of management of MLF to underline the risks and opportunities associated with the different timing of bacterial inoculation during winemaking of valuable white wines.

\section{MATERIALS AND METHODS}

\section{Winemaking procedure}

The experimental winemaking took place in 2014, using Incrocio Manzoni grapes grown on the hills around San
Michele all'Adige (46¹1'45.852" N, 11 $\left.{ }^{\circ} 8^{\prime} 12.070^{\prime \prime} \mathrm{E}\right)$. The vineyard is situated at an altitude of between 250 and 300 meters above sea level, oriented south-west, with a mean slope of $8.5 \%$. The training system adopted was the "Trentino pergola", with a $2.80 \times 0.5 \mathrm{~m}$ planting system. The grapes were manually harvested in the second week of September and then crushed using a pneumatic press. Cleaning of the grape must $(300 \mathrm{~L})$ was performed through cold storage $\left(3^{\circ} \mathrm{C}\right)$ for 48 hours in stainless steel vats; sulphur dioxide was not added in the first steps of winemaking. The grape must obtained had the following chemical composition: sugar $205 \mathrm{~g} / \mathrm{L}, \mathrm{pH} 3.03$, total acidity (as tartaric acid) $10.9 \mathrm{~g} / \mathrm{L}$, tartaric acid $5.0 \mathrm{~g} / \mathrm{L}$, malic acid $7.7 \mathrm{~g} / \mathrm{L}$, and readily assimilable nitrogen $12.5 \mathrm{mg} / \mathrm{L}$. One strain of yeast (S. cerevisiae CY3079 YSEO, Lallemand) and two strains of freeze-dried lactic bacteria, belonging to the $O$. oen $i$ species (Lal1 (PN4) and Lal2 (Lalvin 31), Lallemand Inc., CA), were tested. Traditional winemaking (TW) was carried out with sequential inoculation of $0.3 \mathrm{~g} / \mathrm{L}$ of active dry yeast in the grape must, and $1 \mathrm{~g} / \mathrm{L}$ of lactic bacteria in the wine after racking post-alcoholic fermentation. Simultaneous fermentation (SF), or co-inoculation, was performed using the same microorganisms and the same inoculation rate, but adding the bacteria to the grape must 48 hours after the yeast. In all cases, fermentation was carried out in $20 \mathrm{~L}$ stainless steels vats, with three replicates for each protocol. Data were expressed as mean \pm standard deviation $(n=3)$. Fermentation was carried out under initial nitrogen gas saturation and at a temperature of $22^{\circ} \mathrm{C}$. The wines were cold stabilised and bottled after six months of ageing on the yeast lees, before proceeding with $5.0 \mu \mathrm{m}$ filtration.

\section{Microbiological analysis and yeast/bacteria rehydration} Yeast/bacteria rehydration was carried out according to the OIV method (2015). Counting of the viable and dead yeast cells was performed using flow cytometry (FCM) (Guzzon \& Larcher, 2015). One millilitre of sample containing approximately $10^{5}$ cells, obtained by appropriate dilution in phosphate-buffer saline (PBS), was filtered thought a $30 \mu \mathrm{m}$ filter (CellTrics ${ }^{\circledR}$, Partec GHB, D) and incubated for $10 \mathrm{~min}$ at $20^{\circ} \mathrm{C}$ in the presence of $10 \mu \mathrm{L}$ of a $5 \mathrm{mg} / \mathrm{mL}$ fluorescein diacetate solution (Sigma Aldrich, D). After incubation, samples were mixed and $10 \mu \mathrm{L}$ of $2 \mathrm{mg} / \mathrm{mL}$ propidium iodide solution were added (Sigma Aldrich, D). The double-stained samples were homogenised (30" using a Vortex apparatus, IKA, S) and submitted for FCM analysis within $10 \mathrm{~min}$. FCM analysis was performed using a CUBE 8 Cytometer (Partec), equipped with a solid blue laser emitting at $488 \mathrm{~nm}$. Thanks to four band-pass filters, we considered the following signals: a forward-angle light scatter (FSC), a side-angle light scatter (SSC) and two fluorescence signals, the first with a $530 \mathrm{~nm}$ band-pass filter to collect green fluorescence (FL1 channel), and the second with a $630 \mathrm{~nm}$ long-pass filter to collect red fluorescence (FL2 channel). FCM analysis was performed using logarithmic gains and specific detector settings, adjusted on a sample of unstained Saccharomyces cerevisiae ATTC 9763 to eliminate background and cellular auto-fluorescence. Data were analysed using FCS Express 4 software (De Novo Software Inc., CA). The yeast cell population was identified and gated in the FSC/SSC dot 
plot; live and dead cell differentiation was performed in the FL1/FL2 dot plot, adjusted with appropriate compensation between the two signals by considering the subpopulation of yeast gated in the FSC/SSC dot plot. Quantification of each $O$. oeni strain was performed with a plate count (OIV, 2015) using MRS agar (Oxoid, UK), supplemented with $15 \% \mathrm{v} / \mathrm{v}$ of apple juice. Petri plates were incubated at $25^{\circ} \mathrm{C}$ for four (yeast) and 10 (bacteria) days. These last samples were incubated in anaerobic conditions using an Anaerogen Kit (Oxoid).

\section{Chemical analysis}

The chemical parameters of the grape must and wines were monitored using FT-IR (FOSS, DK) from the chemical laboratory of the Edmund Mach Foundation. Malic and lactic acid quantification was carried out in the grape must during fermentation and in the final wines, using ion chromatography coupled to a conductometric detector (IC/COND), Dionex ICS-5000. Compounds were extracted by solid phase extraction (SPE) using an ENV+ cartridge, as described by Boido et al. (2003). Volatile compound analysis was performed by GC-MSMS using a Varian 450 chromatograph coupled to a Varian 300 TQMS tandem mass spectrometer. The sample extract was injected $(1 \mu \mathrm{L})$ in splitless mode. Injector temperature was $250^{\circ} \mathrm{C}$. Chromatographic separation was performed using a VF-WAXms (30 m x $0.25 \mathrm{~mm}$ ID x $0.25 \mu \mathrm{m}$ film thickness; Agilent Technologies,
$\mathrm{N})$ capillary column with the following oven temperature programme: $40^{\circ} \mathrm{C}$ for $5 \mathrm{~min}$, raised to $150^{\circ} \mathrm{C}$ at $5^{\circ} \mathrm{C} / \mathrm{min}$, finally raised to $240^{\circ} \mathrm{C}$ at $10^{\circ} \mathrm{C} / \mathrm{min}$ and held for 10 minutes. The mass spectrometer was equipped with an electron impact ionisation source (EI) $(70 \mathrm{eV}, 50 \mu \mathrm{A})$, and the acquisition was performed in multiple reaction monitoring (MRM) mode. Transitions and collision energies were those reported by Vrhovsek et al. (2014).

\section{RESULTS AND DISCUSSION}

\section{Evolution of alcoholic fermentation}

One of the main risks of simultaneous inoculation of yeast and bacteria in grape must is related to incompatibility between the microorganisms involved in wine fermentations (Costello et al., 2003), or a modification of yeast activity due to bacterial interference (Rossouw et al., 2012). A careful choice of the yeast and bacterial strains is essential to ensure the absence of negative interactions, such as the production of toxic compounds (e.g. sulphur dioxide, fatty acid, bacteriocins, aromatic alteration). In our tests, no differences were observed in terms of the evolution of alcoholic fermentation rate and/or the viability of the yeast population due to the inoculation of bacteria in fermenting grape must (see Fig. 1 and Table 1). Sugar consumption in the SF trials, containing both yeast and lactic acid bacteria, had the same trend as that observed in the case of conventional winemaking (TW), where selected bacteria were absent

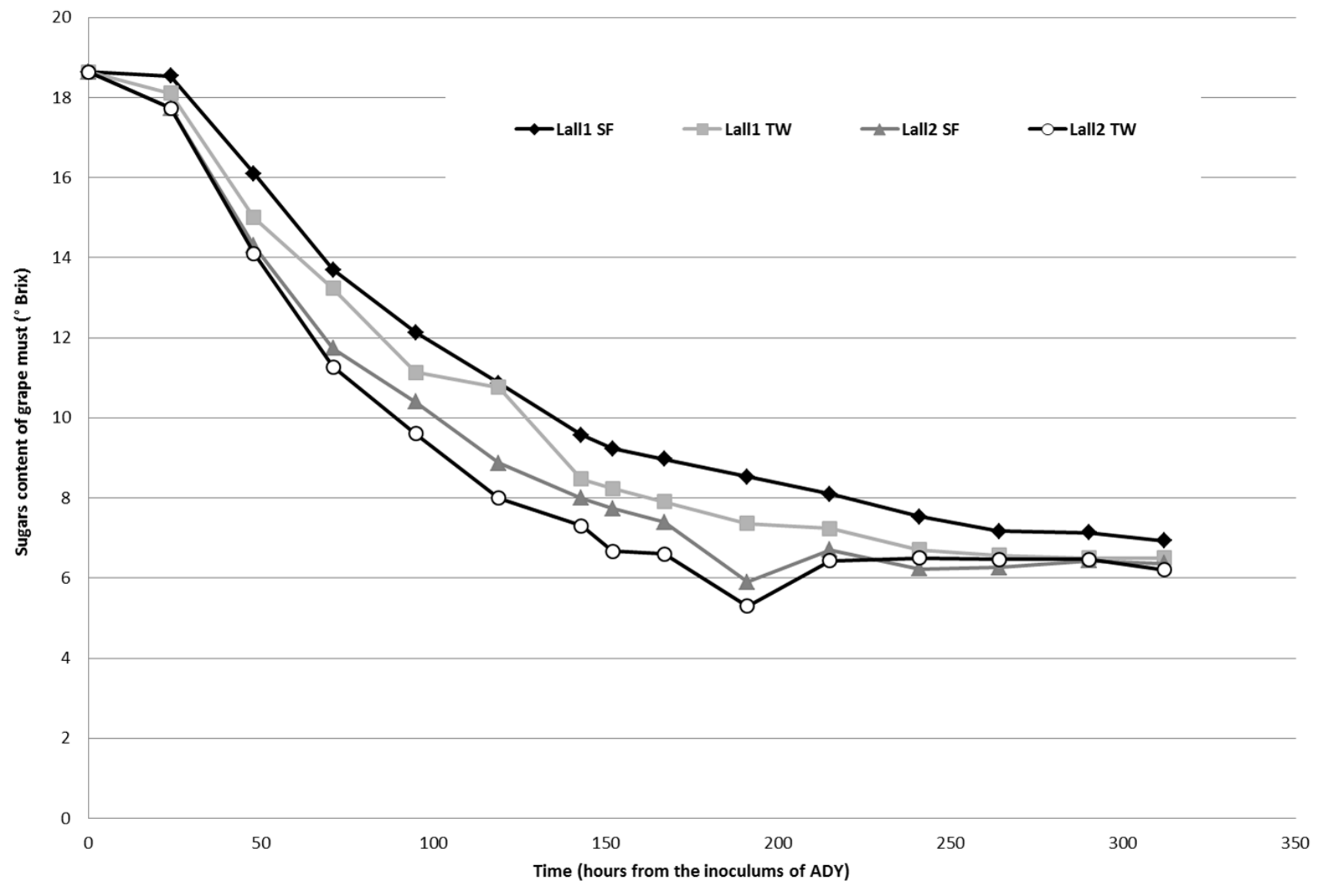

FIGURE 1

Evolution of alcoholic fermentation on the basis of the different microbial strains and oenological fermentation management procedures (mean data, $\mathrm{n}=3$; $\mathrm{SD}<0.1$ ). SF: simultaneous, $\mathrm{TW}$ : traditional inoculation of yeast and bacteria. 
TABLE 1

Evolution of yeast, lactic acid bacteria and malic acid concertation in grape must and wine on the basis of different $O$. oeni strains and oenological fermentation management procedures (AF: alcoholic fermentation, MLF: malolactic fermentation; Mean data $\pm \mathrm{SD}, \mathrm{n}=3$, n.d.: not detectable).

\begin{tabular}{|c|c|c|c|c|c|}
\hline Days & Winemaking step & Trial & $\begin{array}{l}\text { Yeast count (live/dead) } \\
\left(\times 10^{6} \mathrm{cfu} / \mathrm{mL}\right)\end{array}$ & $\begin{array}{l}\text { LAB count } \\
\left(\times 10^{4} \mathrm{cfu} / \mathrm{mL}\right)\end{array}$ & Malic acid (g/L) \\
\hline 4 & $\mathrm{AF}$, inoculation LAB & Lal1 SF & $56 \pm 8.3 / 12 \pm 4.9$ & $5.5 \pm 2.0$ & 6.30 \\
\hline 4 & $\mathrm{AF}$ & Lal1 TW & $55 \pm 5.5 / 14 \pm 4.2$ & n.d. & 6.32 \\
\hline 4 & $\mathrm{AF}$, inoculation $\mathrm{LAB}$ & Lal2 SF & $58 \pm 4.4 / 11 \pm 6.2$ & $4.5 \pm 4.0$ & 6.31 \\
\hline 4 & $\mathrm{AF}$ & Lal2 TW & $55 \pm 8.8 / 10 \pm 4.5$ & n.d. & 6.38 \\
\hline 10 & $\mathrm{AF}$ & Lal1 SF & $31 \pm 5.0 / 22 \pm 4.5$ & - & 4.95 \\
\hline 10 & $\mathrm{AF}$ & Lal1 TW & $30 \pm 8.2 / 19 \pm 3.3$ & - & 5.15 \\
\hline 10 & $\mathrm{AF}$ & Lal2 SF & $32 \pm 4.3 / 23 \pm 6.4$ & - & 5.24 \\
\hline 10 & $\mathrm{AF}$ & Lal2 TW & $30 \pm 8.4 / 19 \pm 3.2$ & - & 5.31 \\
\hline 14 & end of $\mathrm{AF}$ & Lal1 SF & $6.4 \pm 9.2 / 19 \pm 3.0$ & $45 \pm 8.6$ & 4.88 \\
\hline 14 & end of AF, inoculation LAB (day 18) & Lal1 TW & $6.7 \pm 4.2 / 22 \pm 2.0$ & n.d. & 5.03 \\
\hline 14 & end of $\mathrm{AF}$ & Lal2 SF & $7.1 \pm 3.2 / 21 \pm 5.0$ & $0.1 \pm 0.4$ & 5.19 \\
\hline 14 & end of AF, inoculation LAB (day 18) & Lal2 TW & $6.9 \pm 2.2 / 19 \pm 4.5$ & n.d. & 5.09 \\
\hline 25 & MLF & Lal1 SF & - & $160 \pm 22$ & 3.18 \\
\hline 25 & MLF & Lal1 TW & - & $72 \pm 24$ & 4.21 \\
\hline 25 & MLF & Lal2 SF & - & $79 \pm 18$ & 4.93 \\
\hline 25 & MLF & Lal2 TW & - & $0.5 \pm 0.9$ & 5.16 \\
\hline 37 & end of MLF & Lal1 SF & - & $200 \pm 18$ & 0.34 \\
\hline 37 & MLF & Lal1 TW & - & $2.5 \pm 3.3$ & 3.67 \\
\hline 37 & MLF & Lal2 SF & - & $95 \pm 22$ & 4.43 \\
\hline 37 & MLF & Lal2 TW & - & $70 \pm 12$ & 4.56 \\
\hline 45 & - & Lal1 SF & - & $0.3 \pm 0.6$ & $<0.10$ \\
\hline 45 & MLF & Lal1 TW & - & $120 \pm 44$ & 2.12 \\
\hline 45 & MLF & Lal2 SF & - & $76 \pm 43$ & 4.02 \\
\hline 45 & MLF & Lal2 TW & - & $0.3 \pm 0.8$ & 4.89 \\
\hline 60 & - & Lal1 TW & - & $0.5 \pm 1.1$ & n.d. \\
\hline 60 & end of MLF & Lal2 SF & - & $2.1 \pm 0.9$ & n.d. \\
\hline 60 & MLF & Lal2 TW & - & $3.1 \pm 1.2$ & 2.48 \\
\hline
\end{tabular}

during alcoholic fermentation, with complete consumption of the sugar in 16 days.

The duration of the alcoholic fermentations was similar in the SF and TW trials, but too long compared to the general standards, considering the modest degree of alcohol reached (Alexandre et al., 1999; Jimenez-Marti et al., 2011). FCM analysis ensured an overview of the physiological state of yeasts, allowing the measurement of both live and dead cells (Guzzon \& Larcher, 2015). The most interesting data was obtained four days after the inoculation of bacteria in the fermenting must (Table 1), which corresponds to the exponential phase of yeast growth (Ribéreau-Gayon et al., 2004). Viable yeast cells reached a mean of $5.6 \times 10^{7} \mathrm{cell} / \mathrm{mL}$, with no relevant differences between the SF and TW tests. In subsequent observations, performed after five and 10 days of fermentation, the concentration of viable yeast cells decreased according to sugar consumption, but remained comparable in the SF and TW trials. The comparison of data obtained from SF and TW confirmed the absence of negative interactions caused by $O$. oen $i$ with the selected yeast strain involved in the fermentation, which is consistent with previous data obtained under conditions in which strains were chosen for their compatibility, fermentation was carefully monitored and grape must had an adequate supply of nutritional substrates (Abrahamse \& Bartowsky, 2012; Knoll et al., 2012; Guzzon et al., 2013). In our tests, the main stress factors for yeasts were due to the composition of the grape must, linked to the harsh climatic conditions (cold climate, intense hailstorms) characteristics of the 2014 vintage in the Trentino region, which caused a high acidic content and low $\mathrm{pH}$ in the grape must. This phenomenon is underlined by the high number of dead cells already measured four days after inoculation, with a mean of $1.2 \times 10^{7}$ cell $/ \mathrm{mL}$ (Table 1 ), which corresponds to $20 \%$ of the yeast population, a value too high for the first stage of winemaking (Ribéreau-Gayon et al., 2004; Liu et al., 2015).

\section{Evolution of malolactic fermentation}

In contrast to the case with alcoholic fermentation, significant differences in the evolution of MLF were observed, both in 
terms of inoculation timing and the strains of malolactic bacteria utilised. The Lall strain was specifically tailored for resistance to acidic conditions (Guzzon et al., 2009; Izquierdo et al., 2013). This characteristic was confirmed in these tests. In the SF trials, MLF inoculated with Lall took place immediately after alcoholic fermentation, with complete consumption of malic acid in 21 days (Fig. 2). Microbiological analysis (Table 1) showed, that during alcoholic fermentation, the Lall population remained between $5.5 \times 10^{4}\left(5^{\text {th }}\right.$ day) and $4.0 \times 10^{5} \mathrm{CFU} / \mathrm{mL}\left(14^{\text {th }}\right.$ day), growing up to $10^{6} \mathrm{CFU} / \mathrm{mL}$, when the yeasts suffered due to the complete consumption of sugar. In contrast, the growth and activity of the Lall strain inoculated after alcoholic fermentation were negatively influenced by the wine composition. With TW, the bacteria took 44 days to complete MLF and the concentration remained between $7.2 \times 10^{5}\left(25^{\text {th }}\right.$ day $)$ and $1.2 \times 10^{6} \mathrm{CFU} / \mathrm{mL}\left(45^{\text {th }}\right.$ day $)$. The greater effectiveness of lactic bacteria co-inoculation in terms of malic acid degradation was confirmed by the Lal2 strain, despite the difficulties in its development in an acidic environment (Fig. 2, Table 1). With SF, the Lal2 strain achieved MLF, although it took 63 days to carry out the degradation of malic acid, only starting its effective consumption after alcoholic fermentation, when the LAB concentration reached $10^{6} \mathrm{CFU} / \mathrm{mL}$ ( $37^{\text {th }}$ day).

In the case of the TW trial, the degradation of malic acid was not homogenously achieved in the 45 days of observation and, after 60 days, we observed stuck fermentation (data not shown). Evidence of alcoholic fermentation and MLF agreed with data from previous works (Abrahamse \& Bartowski, 2012; Knoll et al., 2012; Izquierdo et al., 2013; Munoz et al., 2014). Using appropriately selected cultures of yeast and bacteria, alcoholic and malolactic fermentation resulted in two independent metabolisms, based on different substrates, without any mutual interference. We also confirmed the major impact of the high acidity of grape must on the bacterial population (Liu \& Gallander, 1983). Although alcoholic fermentation was successfully achieved in all conditions, despite a significant delay, only $\mathbf{S F}$ ensured adequate adaptation of lactic bacteria to the specific wine environment and effective malic acid degradation (Peinado et al., 2000; Liu, 2002; Lonvaud-Funel et al., 2013).

\section{Chemical composition of wines: the main oenological parameters}

The simultaneous inoculation of yeast and bacteria did not affect the composition of the wines in terms of the main chemical parameters (Table 2). We observed homogeneous consumption of sugar (residues in wine below $1.5 \mathrm{~g} / \mathrm{L}$ ), an alcohol concentration of $12.1 \pm 0.04 \% \mathrm{vol} / \mathrm{vol}$, and lactic acid with a final concentration of $2.8 \pm 0.2 \mathrm{~g} / \mathrm{L}$. The accumulation of acetic acid, which is the main marker of spoilage activity due to lactic bacteria in wine during malolactic fermentation (Peinado et al., 2000), did not differ in the four trials. This data confirmed that the two strains of $O$. oeni involved in these tests selectively consumed malic

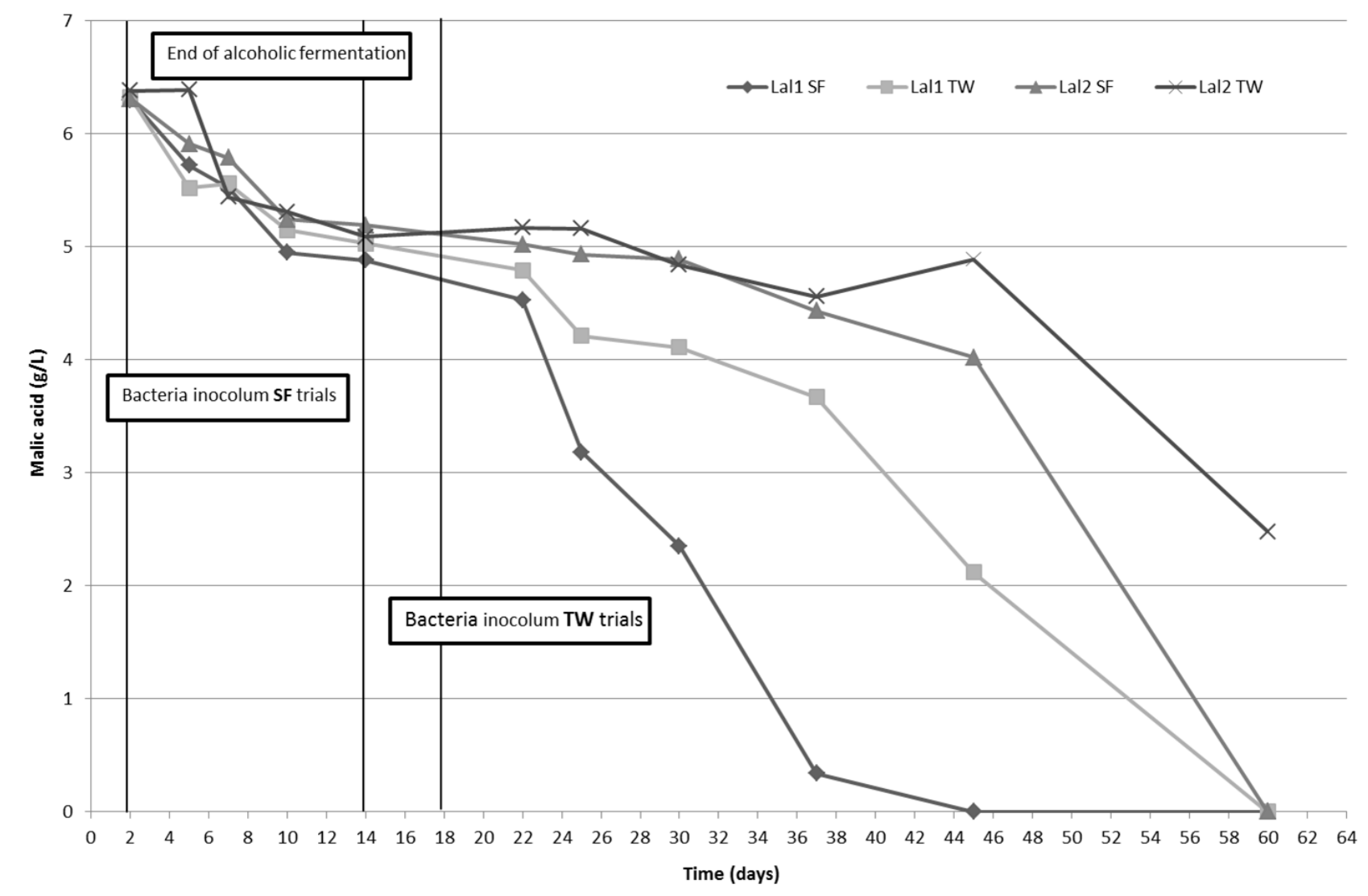

FIGURE 2

Evolution of malic acid concentration during alcoholic and malolactic fermentation (mean data, $\mathrm{n}=3 ; \mathrm{SD}<0.2$ ). SF: simultaneous, TW: traditional inoculation of yeast and bacteria. 
acid as a carbon source in the medium, even in the presence of sugar. The concentration of citric acid was also similar in the different trials (Table 2), with consumption of less than $10 \%$ compared to the initial concentration in the grape must. The low degradation of citric acid is of particular organoleptic importance, since this acid is the second substrate involved in the production of acetic acid, after sugar (Bauer \& Dicks, 2004).

The composition of wines in terms of molecules with olfactory significance appeared to be more complex. Of the 47 compounds investigated, only 25 were above the threshold of detection, as shown in Table 3. The aromatic profile was made up mainly of molecules resulting from secondary yeast metabolism and the fermentation of related compounds, such as the esters of ethylic alcohol with short-chain fatty acids such as butanol and propanol (Peinado et al., 2000). We also observed the presence of other molecules of similar origin, such as the esters of lactic and acetic acid and acetaldehyde. In contrast, the concentration of terpenes and other molecules of direct varietal origin was essentially nil, below the limit of quantification. This absence may be related to the lack of maturity of the grapes due to poor weather conditions in the province of Trento during 2014. In Fig. 3 we compare the volatile profiles from the four experiments. In line with previous experience of similar experimental design (Jussier et al., 2006; Guzzon et al., 2013; Munoz et al., 2014), SF did

TABLE 2

Main chemical parameters of wines at the end of the winemaking (mean data, $\mathrm{n}=3$ ).

\begin{tabular}{lllllllll}
\hline Trial & $\begin{array}{l}\text { Ethanol } \\
(\% \mathrm{vol})\end{array}$ & $\mathbf{p H}$ & $\begin{array}{l}\text { Total acidity } \\
(\mathrm{g} / \mathrm{L})\end{array}$ & $\begin{array}{l}\text { Acetic acid } \\
(\mathrm{g} / \mathrm{L})\end{array}$ & $\begin{array}{l}\text { Sugar } \\
(\mathrm{g} / \mathrm{L})\end{array}$ & $\begin{array}{l}\text { Citric acid } \\
(\mathrm{g} / \mathrm{L})\end{array}$ & $\begin{array}{l}\text { Malic acid } \\
(\mathrm{g} / \mathrm{L})\end{array}$ & $\begin{array}{l}\text { Lactic acid } \\
(\mathrm{g} / \mathrm{L})\end{array}$ \\
\hline Lal1 SF & $12.13 \pm 0.2$ & 3.31 & $4.9 \pm 0.3$ & $0.43 \pm 0.12$ & $1.1 \pm 0.2$ & $0.44 \pm 0.12$ & $<0.35$ & $2.82 \pm 0.2$ \\
Lal1 TW & $12.09 \pm 0.2$ & 3.30 & $4.9 \pm 0.3$ & $0.42 \pm 0.15$ & $1.1 \pm 0.1$ & $0.45 \pm 0.15$ & $<0.35$ & $2.81 \pm 0.3$ \\
Lal2 SF & $12.03 \pm 0.1$ & 3.28 & $5.1 \pm 0.1$ & $0.46 \pm 0.10$ & $1.2 \pm 0.0$ & $0.48 \pm 0.22$ & $<0.35$ & $2.77 \pm 0.1$ \\
Lal2 TW & $12.07 \pm 0.2$ & 3.28 & $5.0 \pm 0.2$ & $0.44 \pm 0.10$ & $1.3 \pm 0.2$ & $0.44 \pm 0.18$ & $1.06 \pm 1.00$ & $2.50 \pm 0.5$ \\
\hline
\end{tabular}

TABLE 3

Aromatic profile of wines obtained using different fermentation protocols (mean data, $\mathrm{n}=3$ ).

\begin{tabular}{|c|c|c|c|c|c|c|c|c|}
\hline Volatile compound & $\begin{array}{l}\text { SF Lal1 } \\
\mathrm{mg} / \mathrm{L}\end{array}$ & $\begin{array}{l}\text { RSD } \\
\%\end{array}$ & $\begin{array}{l}\text { TW Lal1 } \\
\mathrm{mg} / \mathrm{L}\end{array}$ & $\begin{array}{l}\text { RSD } \\
\%\end{array}$ & $\begin{array}{l}\text { SF Lal2 } \\
\mathrm{mg} / \mathrm{L}\end{array}$ & $\begin{array}{l}\text { RSD } \\
\%\end{array}$ & $\begin{array}{l}\text { TW Lal2 } \\
\mathrm{mg} / \mathrm{L}\end{array}$ & $\begin{array}{l}\text { RSD } \\
\%\end{array}$ \\
\hline 3-Methylbutanol & $109.6 \pm 2.2$ & 2.0 & $114.8 \pm 2.5$ & 2.2 & $116.6 \pm 2.9$ & 2.5 & $118.5 \pm 7.6$ & 6.4 \\
\hline Ethyl lactate & $94.5 \pm 50.1$ & 53.0 & $84.6 \pm 63.9$ & 75.6 & $61.5 \pm 25.8$ & 41.9 & $46.8 \pm 19.5$ & 41.8 \\
\hline Ethyl acetate & $52.5 \pm 2.2$ & 4.2 & $48.6 \pm 2.0$ & 4.1 & $46.6 \pm 0.5$ & 1.1 & $41.6 \pm 0.3$ & 0.7 \\
\hline Methanol & $34.6 \pm 0.8$ & 2.2 & $34.9 \pm 1.1$ & 3.2 & $32.9 \pm 1.0$ & 3.0 & $34.8 \pm 0.2$ & 0.6 \\
\hline 2-Methyl-1-propanol & $26.7 \pm 0.3$ & 1.1 & $27.1 \pm 0.6$ & 2.2 & $27.7 \pm 0.5$ & 1.9 & $28.5 \pm 1.1$ & 3.7 \\
\hline 1-Propanol & $28.1 \pm 0.9$ & 3.1 & $29.5 \pm 0.2$ & 0.8 & $30.4 \pm 0.4$ & 1.4 & $30.4 \pm 1.2$ & 4.1 \\
\hline 2-Methylbutanol & $18.9 \pm 0.3$ & 1.3 & $19.7 \pm 0.3$ & 1.4 & $19.8 \pm 0.2$ & 0.9 & $20.6 \pm 1.0$ & 5.1 \\
\hline Isopentyl acetate & $6.7 \pm 0.4$ & 6.2 & $6.0 \pm 1.6$ & 26.0 & $4.3 \pm 1.1$ & 25.7 & $5.0 \pm 1.1$ & 21.3 \\
\hline Octanoic acid & $3.8 \pm 2.4$ & 62.9 & $4.6 \pm 1.1$ & 24.1 & $6.3 \pm 0.6$ & 9.3 & $7.1 \pm 0.7$ & 9.5 \\
\hline Hexanoic acid & $2.7 \pm 1.3$ & 48.4 & $3.4 \pm 0.6$ & 18.5 & $4.3 \pm 0.5$ & 12.6 & $4.8 \pm 0.4$ & 8.2 \\
\hline 2-Phenylethanol & $8.0 \pm 1.6$ & 20.5 & $9.3 \pm 1.3$ & 13.6 & $11.3 \pm 1.8$ & 15.9 & $10.7 \pm 2.0$ & 18.5 \\
\hline Ethyl hexanoate & $0.8 \pm 0.1$ & 12.6 & $0.7 \pm 0.1$ & 16.5 & $0.7 \pm 0.1$ & 12.4 & $0.7 \pm 0.1$ & 6.9 \\
\hline Acetaldehyde & $6.0 \pm 0.5$ & 9.1 & $6.2 \pm 0.4$ & 6.0 & $8.6 \pm 1.4$ & 16.4 & $6.8 \pm 1.5$ & 22.1 \\
\hline 1-Hexanol & $2.3 \pm 0.4$ & 19.4 & $2.1 \pm 0.6$ & 27.4 & $2.1 \pm 0.0$ & 1.3 & $1.9 \pm 0.2$ & 10.3 \\
\hline Ethyl octanoate & $0.5 \pm 0.1$ & 27.9 & $0.5 \pm 0.1$ & 10.2 & $0.6 \pm 0.1$ & 17.8 & $0.7 \pm 0.0$ & 5.4 \\
\hline Isobutyric acid & $1.4 \pm 0.1$ & 6.3 & $1.4 \pm 0.1$ & 5.3 & $1.4 \pm 0.2$ & 15.4 & $1.6 \pm 0.1$ & 8.7 \\
\hline Diethyl-succinate & $0.4 \pm 0.2$ & 58.5 & $0.6 \pm 0.1$ & 12.3 & $1.4 \pm 0.1$ & 9.5 & $1.3 \pm 0.4$ & 28.8 \\
\hline Butanoic acid & $1.3 \pm 0.1$ & 11.4 & $1.4 \pm 0.1$ & 9.3 & $1.5 \pm 0.2$ & 15.5 & $1.7 \pm 0.1$ & 5.3 \\
\hline Cis-3-hexen-1-ol & $0.3 \pm 0.1$ & 20.1 & $0.3 \pm 0.1$ & 21.8 & $0.3 \pm 0.0$ & 4.0 & $0.2 \pm 0.0$ & 6.4 \\
\hline 3-(Methylthio)-1-propanol & $0.3 \pm 0.1$ & 24.9 & $0.3 \pm 0.0$ & 13.5 & $0.4 \pm 0.1$ & 16.0 & $0.4 \pm 0.0$ & 4.7 \\
\hline Ethyl butyrate & $0.3 \pm 0.1$ & 20.7 & $0.4 \pm 0.1$ & 24.1 & $0.3 \pm 0.1$ & 27.1 & $0.4 \pm 0.0$ & 1.9 \\
\hline$n$-Butyl acetate & $1.1 \pm 0.3$ & 25.5 & $1.1 \pm 0.1$ & 12.2 & $1.0 \pm 0.1$ & 13.8 & $1.3 \pm 0.2$ & 17.1 \\
\hline Decanoic acid & $1.1 \pm 0.7$ & 62.4 & $1.2 \pm 0.5$ & 42.4 & $2.2 \pm 0.2$ & 10.6 & $2.4 \pm 0.2$ & 8.8 \\
\hline Ethyl decanoate & 0.0 & - & 0.0 & - & $0.1 \pm 0.0$ & 31.3 & $0.1 \pm 0.0$ & 17.5 \\
\hline Valeric acid & 0.0 & - & 0.0 & - & 0.0 & 10.4 & 0.0 & 3.8 \\
\hline
\end{tabular}




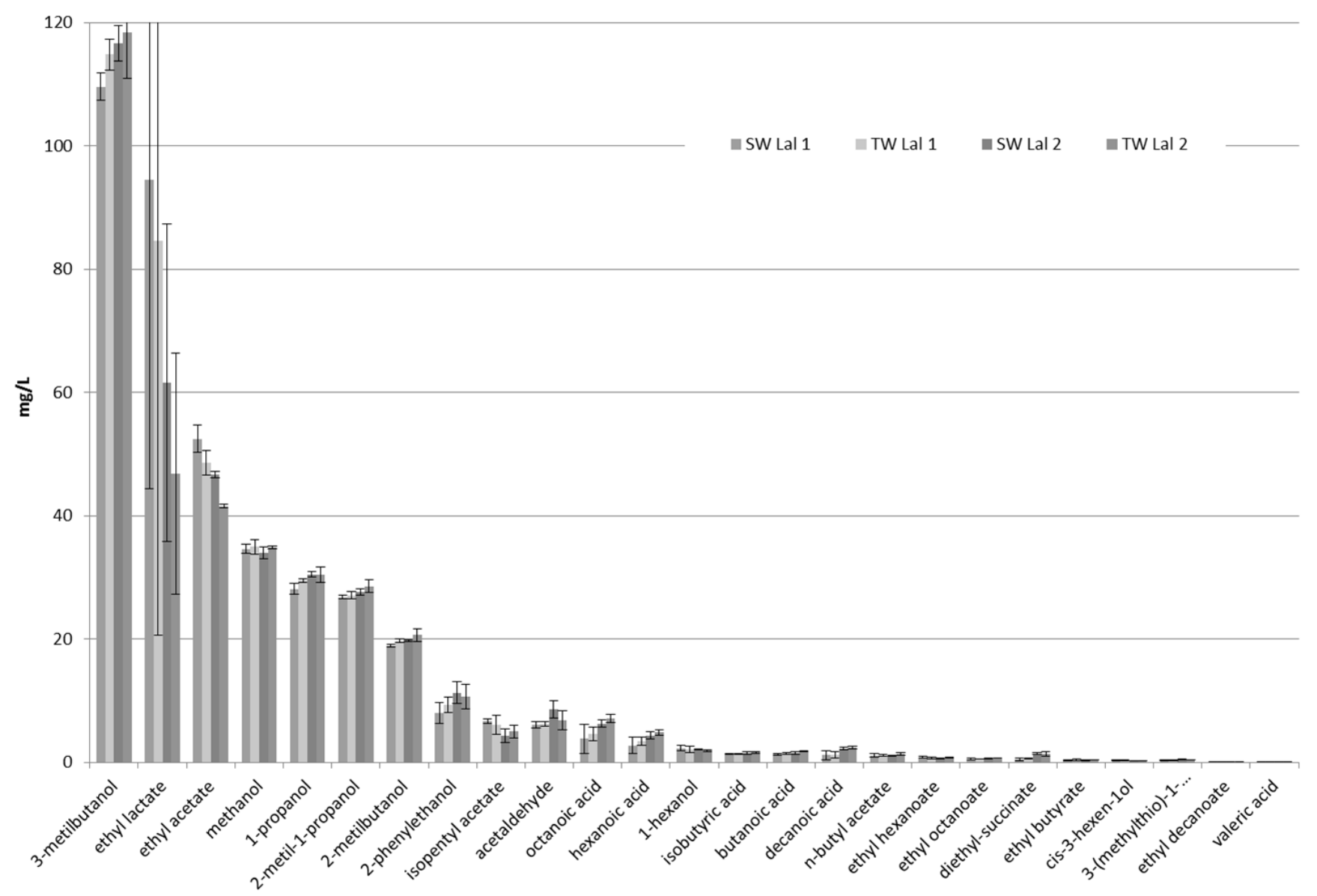

FIGURE 3

Volatile profile of four wines obtained using different experimental winemaking protocols. (mean data, $n=3$ ). SF: simultaneous, TW: traditional inoculation of yeast and bacteria.

not significantly alter the patterns of volatiles, maintaining the native features of wines. This behaviour contrasts to that observed by Rossouw et al. (2012) regarding the induction of a specific genetic expression of yeast, due to the presence of LAB during alcoholic fermentation. However, it is reasonable to believe that the stress exerted by the harsh must/wine composition played a dominant role in the modulation of the activity of microorganisms in respect to the interaction among the different microbial genera present in the fermentation environment. Another reason could be found in the careful choice of the groups of yeast/bacteria strains aimed to minimise negative interactions among them. The main observed differences seemed to be related to the bacterial strains involved in MLF, with Lall able to accumulate ethyl esters, while Lal2 activity enhanced methyl-derivate compounds (the concentration of methanol did not change in the four trials). The different winemaking protocols did not alter this trend and, indeed, seemed to enhance the differences, since there is evidence that the SF Lal1 and TW Lal2 tests represented the extremes, regardless of the concentration, for most of the volatile compounds.

\section{CONCLUSIONS}

The experiences described in this work demonstrate that simultaneous fermentation of yeast and bacteria (coinoculation) may be an interesting winemaking strategy, not only for international grape varieties, but also for "traditional" grapes. This is remarkable, given that many "traditional" vine varieties are grown in extreme environmental conditions that alter the composition of the grape must, with the presence of factors that affect the activity of lactic acid bacteria. In our case, the chemical composition of grape must resulting from a poor vintage in a mountain vineyard was characterised by high acidity, which represented a serious barrier to malolactic fermentation, which was carried out at the end of alcoholic fermentation. While simultaneous inoculation facilitated MLF, some differences were highlighted, both in terms of fermentation kinetics and the aromatic profile of the wines obtained, in relation to the strain of lactic bacteria used. However, careful choice of the Oenococcus oeni strain involved in SF ensured the absence of spoilage activity, accompanied by prompt analytical control, in some cases using FCM, which allowed early identification of potential problems. If carried out in this context, the simultaneous fermentation of yeast and bacteria represents a valuable alternative to traditional winemaking protocols.

\section{LITERATURE CITED}

Abrahamse, C. \& Bartowsky, E.J., 2012. Timing of malolactic fermentation inoculation in Shiraz grape must and wine: Influence on chemical composition. World J. Microbiol. Biotechnol. 28(1), 255-265. 
Alexandre, H., Bertrand, F. \& Charpentier, C., 1999. Effect of ethanol on yeast film formation. J. Int. Sci. Vigne Vin 33(1), 25-29.

Bartowsky, E., Costello, P.J. \& Chambers, P.J., 2015. Emerging trends in the application of malolactic fermentation. Aust. J. Grape Wine Res. 21. doi:10.1111/ajgw.12185

Bauer, R. \& Dicks, L.M.T., 2004. Control of malolactic fermentation in wine. A review. S. Afr. J. Enol. Vitic. 25(2), 74-87.

Boido, E., Loret, A., Medina, K., Farina, L., Carrau, F., Versini, G. \& Dellacassa, E., 2003. Aroma composition of Vitis vinifera cv. Tannat: The typical red wine from Uruguay. J. Agr. Food. Chem. 51(18), 5408-5413.

Comitini, F. \& Ciani, M., 2007. The inhibitory activity of wine yeast starters on malolactic bacteria. Ann. Microbiol. 57(1), 61-66.

Costello, P.J., Henschke, P.A. \& Markides, A.J., 2003. Standardized methodology for testing malolactic bacteria and wine yeast compatibility. Aust. J. Grape Wine Res. 9, 127-137.

Coucheney, F., Desroche, N., Bou, M., Tourdot-Marechal, R., Dulau, L. \& Guzzo, J. 2005. A new approach for selection of Oenococcus oeni strains in order to produce malolactic starters, Int. J. Food. Microbiol. 105(3), 463470 .

Drici Cachon, Z., Guzzo, J., Cavin, J.F. \& Divies, C., 1996. Acid tolerance in Leuconostoc oenos. Isolation and characterization of an acid-resistant mutant. Appl. Microbiol. Biotechnol. 44, 785-789.

Francesca, N., Settanni, L., Sannino, C., Aponte, M. \& Moschetti, G., 2011. Ecology and technological capability of lactic acid bacteria isolated during Grillo grape vinification in Marsala area production. Ann. Microbiol. 61, 79-84.

Guzzo, J., Coucheney, F., Pierre, F., Fortier, L., Delmas, F., Dives, C. \& Tourdot-Maréchal, R., 2002. Acidophilic behaviour of the malolactic bacterium Oenococcus oeni. Sci. Alim. 22(1-2), 107-111.

Guzzon, R. \& Larcher, R., 2015. The application of flow cytometry in microbiological monitoring during winemaking: Two case studies. Ann. Microbiol. 65(4), 1865-1878.

Guzzon, R., Poznanski, E., Conterno, L., Vagnoli, P., Krieger-Weber, S. \& Cavazza, A., 2009. Selection of a new highly resistant strain for malolactic fermentation under difficult conditions. S. Afr. J. Enol. Vitic. 30(2), 133141 .

Guzzon, R., Villega, T.R., Pedron, M., Malacarne, M., Nicolini, G. \& Larcher, R., 2013. Simultaneous yeast-bacteria inoculum. A feasible solution for the management of oenological fermentation in red must with low nitrogen content. Annal. Microbiol. 63(2), 805-808.

Henick-Kling, T. 1993. Malolactic fermentation. In: Fleet, G.H. (ed.). Wine microbiology and biotechnology. Harwood Academic Publisher, Chur. pp. $290-326$.

Izquierdo., P.M.C., Romero, E.G., Martín, F.P., Prieto, S.S., Manso, J.M.H \& Herreros, M.L.P., 2013. Behaviour during malolactic fermentation of three strains of Oenococcus oeni used as direct inoculation and acclimatization cultures. S. Afr. J. Enol. Vitic. 34(1)

Jimenez-Marti, E., Gomar-Alba, M., Palacios, A., Ortiz-Julien, A. \& Olmo, M.L., 2011. Towards an understanding of the adaptation of wine yeasts to must: Relevance of the osmotic stress response. Appl. Microb. Biotechnol. 89(5), 1551-1561

Jussier, D., Dube Morneau, A. \& De Orduna, R.M., 2006. Effect of simultaneous inoculation with yeast and bacteria on fermentation kinetics and key wine parameters of cool-climate Chardonnay. Appl. Environ. Microbiol. 72(1), 221-227.
Knoll, C., Fritsch, S., Schnell, S., Grossmann, M., Krieger-Weber, S., Du Toit, M. \& Rauhut, D., 2012. Impact of different malolactic fermentation inoculation scenarios on Riesling wine aroma. W. J. Microbiol. Biotechnol. 28(3), 1143-1153

Lasik, M. 2013. The application of malolactic fermentation process to create good-quality grape wine produced in cool-climate countries: A review. Eu. Food Res. Technol. 237(6), 843-850.

Liu, J.W.R. \& Gallander, J.F., 1983. Effect of pH and sulphur dioxide on the rate of malolactic fermentation in red table wines. Am. J. Enol. Vitic. 34(1), 44-46.

Liu, S.Q. 2002. Malolactic fermentation in wine. Beyond deacidification. J. Appl. Microbiol. 92, 589-601.

Liu, X.Y., Jia, B., Sun, X.Y., Ai, J.Y., Wang, L.H., Wang, C., Zhao, F., Zhan, J.C. \& Huang, W.D., 2015. Effect of initial pH on growth characteristics and fermentation properties of Saccharomyces cerevisiae. J. Food Sci. 80(4), M800-M808.

Lonvaud-Funel, A. 1999. Lactic acid bacteria in the quality improvement and appreciation of wine. Antonie van Leeuwenhoek J. Microbiol. 76, 317 331.

Munoz, V., Beccaria, B. \& Abreo, E., 2014. Simultaneous and successive inoculations of yeasts and lactic acid bacteria on the fermentation of an unsulfited Tannat grape must. Brazilian J. Microbiol. 45(1), 59-66.

OIV., 2015. Recueil international des méthodes d'analyses. Analyse microbiologique des vins et des moûts.

Pan, W. \& De Orduna, R.M., 2006. Simultaneous alcoholic and malolactic fermentations in Chardonnay at different wine $\mathrm{pH}$ values. Am. J. Enol. Vitic. 57(4), 528-538.

Peinado, R.A., Moreno, J.A., Muñoz, D., Medina, M. \& Moreno, J., 2000. Gas chromatographic quantification of major volatile compounds and polyols in wine by direct injection. J. Agr. Food Chem. 52(21), 6389-6393.

Renouf, V., 2013. La fermentation malolactique dans les vins. Mécanismes et applications pratiques. Lavoisier, Paris.

Ribéreau-Gayon, P., Dubourdieu, D., Doneche, B. \& Lonvaud, A., 2004. Traité d'œnologie. Tome 1: Microbiologie du vin, Vinifications. Dunod, Paris.

Rosi, I., Fia, G. \& Canuti, V., 2003. Influence of different $\mathrm{pH}$ values and inoculation time on the growth and malolactic activity of a strain of Oenococcus oeni. Aust. J. Grape Wine Res. 9, 194-199.

Rossouw, D., Du Toit M. \& Bauer F.F., 2012. The impact of co-inoculation with Oenococcus oeni on the transcriptome of Saccharomyces cerevisiae and on the flavour-active metabolite profiles during fermentation in synthetic must. Food Microbiol. 29(1), 121-131.

Spano, G., Russo, P., Lonvaud-Funel, A., Lucas, P., Alexandre, H., Grandvalet, C., Coton, E., Coton, M., Barnavon, L., Bach, B., Rattray, F., Bunte, A., Magni, C., Ladero, V., Alvarez, M., Fernández, M., Lopez, P., De Palencia, P.F., Corbi, A., Trip, H. \& Lolkema, J.S., 2010. Biogenic amines in fermented foods. Eur. J. Clin. Nutr. 64(3): S95-S100.

Vrhovsek, U., Lotti, C., Masuero, D., Carlin, S., Weingart, G. \& Mattivi, F., 2014. Quantitative metabolic profiling of grape, apple, and raspberry volatile compounds (VOC) using a GC/MS/MS method. J. Chromatogr. B, 966, 132-139.

Wibowo, D., Eschenbruch, R., Davis, C.R., Fleet, G.H. \& Lee, T.H., 1985. Occurrence and growth of lactic acid bacteria in wine: a review. Am. J. Enol. Vitic. 36(4), 302-313.

Zapparoli, G., Tosi, E., Azzolini, M., Vagnoli, P. \& Krieger, S. 2009. Bacterial inoculation strategies for the achievement of malolactic fermentation in high-alcohol wines. S. Afr. J. Enol. Vitic. 30(1), 49-55. 